\title{
IJIKMMENA
}

3,2

\section{OBSTACLES TO INNOVATION FACED BY SMALL AND MEDIUM ENTERPRISES (SMES) IN LIBYA}

\author{
Emhamad Elmansori' \\ Omar Al-Mukhtar University, Libya \\ Leslie Arthur ${ }^{2}$ \\ Nottingham Trent University, UK
}

\begin{abstract}
Purpose: This paper aims to discuss the obstacles faced by innovation in SMEs in Libya. Libyan SMEs have relatively low value added, though they represent a significant portion of Libyan firms. According to previous research, SMEs are facing a financing gap that causes under-capitalisation and hinders economic growth. This paper also analyses the current situation of SMEs in Libya and addresses the question of whether the financing problem still exists.

Design methodology/approach: To meet this aim, the study undertook a snowball approach and distributed a designed questionnaire to the Libyan SMEs, after which 91 responses were obtained out of 400 questionnaires. Findings: The findings of the paper show that access to external finance is still a significant factor for Libyan SMEs. Independent governmental bodies or business incubators that can facilitate access to funding from the relevant public and private sectors are recommended in order to close this financing gap.

Originality/value: Knowledge of the critical challenges faced by innovation in SMEs in Libya remains scant and incomplete. The authors believe that this paper has concluded with a number of recommendations that need to be adopted by the policy makers to help alleviate problems of the non-availability of finance to the SMEs sector.
\end{abstract}

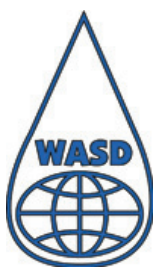

International Journal of Innovation and Knowledge Management in Middle East \& North Africa Vol. 3 No. 2, 2014

Copyright (C) 2014 WASD

${ }^{1}$ Emhamad Elmansori, Faculty of economics, Omar Al-Mukhtar University, LIBYA, Email: elmansori2010@yahoo.co.uk

${ }^{2}$ Leslie Arthur, Product Design, School of Architecture, Design and the Built Environment, Nottingham Trent University, UK, Email: Leslie.Arthur@ntu.ac.uk 
Keywords: Small Eु Medium Enterprises, Innovation, Financing, Obstacles, Libya

Paper type: Research paper

Obstacles to innovation

faced by small and medium enterprises

\section{INTRODUCTION}

During the twentieth century, the SMEs sector played an important role in the economies of the majority of the developed countries. Bolton's report in the UK (Bolton, 1971) is widely attributed to have been one of the first significant attempts by a government to develop an informed view of the nature of the SMEs sector and its role in the economy. Since then, many researchers have demonstrated the significant role of SMEs in both developed and developing economies in combating unemployment and increasing the rate of economic growth and innovation (Eltaweel, 2011).

According to different perspectives of researchers, the market experiment of innovation is responsible for bringing sweeping changes which primarily restructure markets and industries. Similarly, the nonclassical view of economics states that innovation is strategically an aspect of business or a division of investment decision sets for creating the capacity to develop and improve the capacity of the product. Innovation within SME companies has become a subject of much interest. Competitive pressures and globalisation have provided the impetus for innovation (Birchall et al., 1996). Around the world, Innovation in SMEs face the same obstacles: either financial, especially the limited access to external funding, as well as non-financial, related to knowhow, marketing, accounting and other business aspects of management. The limited access to external funding, which is mainly represented in debt, especially bank loans, is associated with the unattractiveness of SMEs from the creditor point of view. Bank loans require credit history, collaterals and projections of future cash flows that are typically unavailable for SMEs (El-Kabbani and Kalhoefer, 2011).

In Libya, the exact number of SMEs is still unknown, but the Ministry of Trade and Economy in 2006 estimated the number of small businesses in Libya at 180,000. However, some Libyan officials believe that there are many other unofficial or informal businesses, as SMEs often operate outside the formal economy to avoid taxation and other fiscal and regulatory considerations (Eltaweel, 2011; Porter and Yergin, 2006). 
IJIKMMENA

3,2

Numerous studies have found that countries can improve their economies through enhancing their SMEs sector (Eltaweel, 2011; Bhaird and Lucey, 2009; Marcketti and Kozar, 2007; Asiedu and Freeman, 2006; Meyer, 1998; Berry and Levy, 1994; University of Cambridge, 1992; Dyson, 1990; Burns and Dewhurst, 1986; Gallagher and Stewart, 1984). They discovered that SMEs can play a significant role in terms of generating income, developing skills, absorbing labour, and alleviating poverty, increasing innovation and forming linkage between sectors, which can be economically and geographically diverse.

Therefore, this paper focuses on the situation of obstacles that hinder innovation in SMEs in Libya. Based on primary data which has been gathered using questionnaires, this empirical paper has two main objectives: the first one is to explore the SMEs environment in Libya and also to shed light on the main constraints for Libyan SMEs. The second objective is to determine the obstacles to innovation faced by SMEs in Libya. In addition, the current situation of SMEs in Libya will be analysed, and the question of whether or not the financing problem still exists will be addressed.

\section{BACKGROUND AND DEFINITION OF SMES}

In general terms, there is no standard definition of SMEs: instead the concept has been used in different contexts using various meanings. McMahon et al. (1993:9) stated that to define small firms, there is "a vexing enduring difficulty". The authors pointed out that small businesses are simpler to describe than to define in exact terms. Stokes and Wilson (2010), Wong and Aspinwall (2004) and Holmes and Gibson (2001) found that one important issue is how to define small businesses clearly and how they can be differentiated from large firms.

The definitions used by federal and provincial governments, as well as by private parties, are usually based upon qualitative or quantitative criteria, or on a mix of both, which, it could be argued, is the ideal scenario for the purposes of defining and identifying SMEs. The most common qualitative aspects used to define the term include an SME's geographical scale or operations, degree of independence and type of management (Intarakamnerd et al., 2002).

Small and medium enterprises differ markedly in size, organisation and type of activity. The complexity and structure of the management of 
an undertaking also serve to discern SMEs from larger entities. Usually, large enterprises tend to be managed by skilled professional people who are charged with hierarchical authority. Administrative roles are also divided up according to a company's operational functions (traditionally: production, sales, financing, marketing, etc.). Conversely, SMEs are frequently administered by personal or direct management (Balzat and Hanusch, 2004). The concept of personal or direct management in SMEs refers to persons who usually own and operate the undertaking and do not receive remuneration in the form of a salary for the services they render to the SMEs.

SMEs stands for small and medium enterprises. This is a commercial, industrial or other company that has a small number of workers and moderate income records. Another such term is MSMEs, the acronym for micro, small and medium enterprises, which also includes smaller firms, such as sole proprietorships. The definition of SMEs varies by country. Argentina, for example, ranks companies according to their annual sales and their area (an industrial SME can have a turnover which in other economic sectors, would place the company among the largest). In other countries, the concept of the SME is associated with the number of employees. Between one and ten employees, the company is termed micro; between 11 and 50, it is termed an SME. These figures, however, may vary according to region (Awang, 2004).

SMEs have specific needs that must be met by the state. Such companies generate huge revenues for each country, and are also one of the main drivers of employment. However, because of their size, they need protection and incentives to compete against large corporations. Credit lines with special conditions, tax benefits and free consulting are some of the tools that are offered by the state in order to allow SMEs to develop.

Defining small and medium enterprises can be confusing based on certain criteria. For instance, on the one hand definitions based on turnover alone must be adjusted in terms of inflation. On the other hand, there are some businesses which have a number of workers that may be considered small, although they have high turnover. Curran and Blackburn (2001:9) found that the number of employees in enterprises is extremely popular with researchers and policy makers alike. While being highly popular and very easy to use, these criteria require some care when they are adopted. Financial turnover is also used as
Obstacles to innovation faced by small and medium enterprises (SMES) in Libya

204 
IJIKMMENA an alternative and apparently attractive measure of size. Despite the 3,2 number of employees being one of the most widely employed criteria, care must be taken when, for instance, treating a part-time worker as the equal of half a full-time worker. Moreover, from country to country the number of employees used varies according to the objective of the definition. For example, one industry may define businesses as small, but this does not mean that all other manufacturers have the same standard to define their small businesses (Eltaweel, 2011).

Bolton (1971) suggested that to be defined as small, the turnover of a retailer must not exceed $£ 200,000$. The MENA (Middle East and North Africa), according to the United Nations Development Programme (2011), summarised the MENA SMEs definitions as shown in the following table.

\section{RESEARCH METHODOLOGY}

As a result of the difficulties in contacting all SMEs in Libya, the sampling approach used was "snowball sampling", in which a number of SMEs that fit the definition were asked to complete the questionnaire, then the participants forwarded the questionnaire to others they know matching the same definition (Welch, 1975). Using the snowball sampling method, 91 responses were obtained out of 400 questionnaires distributed, leading to a response rate of around $22.75 \%$. The questionnaire was developed in English and later translated into Arabic (the translation was checked

\begin{tabular}{lll}
\hline Country & Small & Medium \\
\hline Egypt & 5 to 14 employees & 15 to 49 employees \\
Lebanon & 10 to 49 employees & 50 to 99 employees \\
Oman & 6 to 20 employees & 21 to 100 employees \\
Jordan & 5 to 19 employees & 20 to 99 employees \\
UAE & 10 to 49 employees & 50 to 499 employees \\
Tunisia & 11 to 49 employees & 50 to 99 employees \\
$*$ Libya & Less than 25 employees & Less than 50 employees \\
\hline
\end{tabular}

Table I. Standard definitions of SMEs across MENA
Source: Jordan Human Development Report, 2011, United Nations Development Programme (Amman-Jordan).

*National Council for Economic Development - Libya 2011. 
by a member of staff from Nottingham Trent University, who speaks and writes both languages excellently) to be distributed, since it is the official language of Libya, but the owners of SMEs will not necessarily be literate in English. In order to ascertain the validity of the research instrument used, a panel of experienced academics were consulted and modifications to the questionnaire were made according to their constructive recommendations. The sequence and wording of some of the questions were changed to make them more understandable and relevant to the dimensions being studied and some scales were modified to better match the purposes of the research. The face validity of the questionnaire was therefore improved (Ghauri and Gronhaug, 2005; El-Kabbani and Kalhoefer, 2011).

According to the research needs of the targeted firms, the survey data collection process took place from October 2011 to April 2012. The questionnaires were sent to the selected firms during this period. Reminders were also sent to the participants. The first reminder was sent two weeks after distribution, the second was sent after a month, and the third and final reminder was sent in April 2012, especially for nonresponse participants.

Due to the recent uprising in Libya, responses from SMEs were extended until the end of April 2012. The final reminder was sent in early April in order to boost the response rate, and in case of e-mails being lost or forgotten because of the political circumstances. From a total of 400 enterprises initially selected for this research, 91 usable responses were received (22.75\% response rate). Two questionnaires were not completed and were not usable and were therefore excluded from the final count.

\section{DATA ANALYSIS AND FINDINGS}

According to the respondents, the SMEs have been running for the last 30 years and were established between 1980 and 2010. Table 1 shows the frequency and per cent of firms established by year.

Table 1 shows that only 13 (14\%) of the sample firms were established after 2005 and most of them, i.e. 38 (42\%) were established between 1998 and 1999.

It can be seen from Figure 1 that $16.5 \%$ of the business in Libya is manufacturing, $14.3 \%$ is agriculture, $13.2 \%$ is healthcare, $7.7 \%$ is
Obstacles to innovation faced by small and medium enterprises (SMES) in Libya 206

(n)




\begin{tabular}{llll}
\cline { 2 - 4 } IJIKMMENA & & Frequency & Per cent \\
\cline { 2 - 4 } & 1980 & 2 & 2.2 \\
& 1986 & 1 & 1.1 \\
& 1992 & 9 & 9.9 \\
207 & 1998 & 13 & 14.3 \\
\hline & 1999 & 25 & 27.5 \\
& 2000 & 7 & 7.7 \\
& 2002 & 6 & 6.6 \\
& 2005 & 15 & 16.4 \\
& 2006 & 4 & 4.4 \\
& 2007 & 5 & 5.5 \\
& 2008 & 2 & 2.2 \\
$\begin{array}{l}\text { Table 2. Per cent of } \\
\text { SMEs reporting date } \\
\text { of establishment }\end{array}$ & 2009 & 1 & 1.1 \\
\cline { 2 - 5 } & Total & 1 & 1.1 \\
\hline
\end{tabular}

Figure I. Business sectors

\section{Business Sectors}

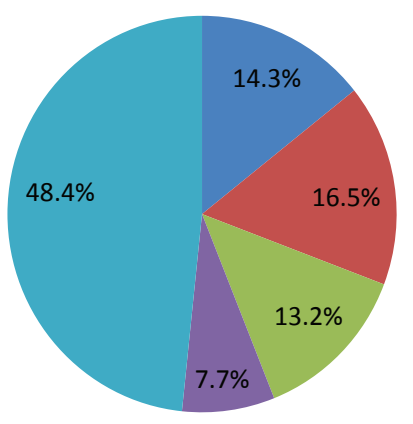

Agriculture

- Manufacturing

Healthcare

Tourism

Other 

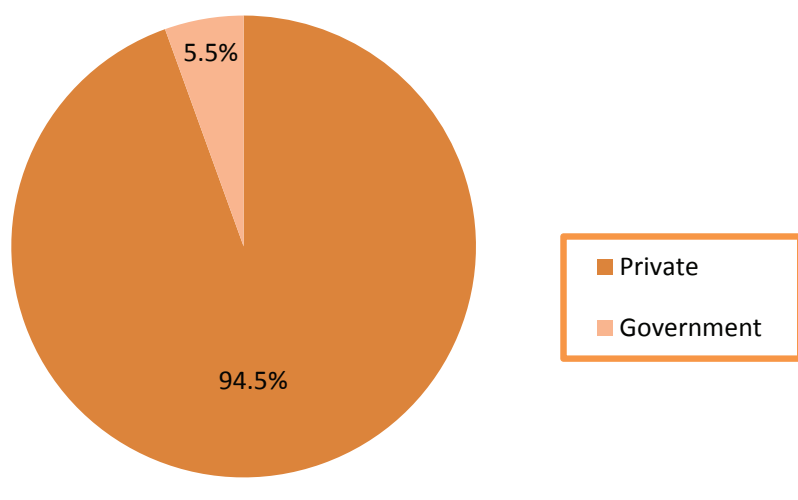

Obstacles to innovation faced by small and medium enterprises (SMES) in Libya 208

Figure 2. Type of business

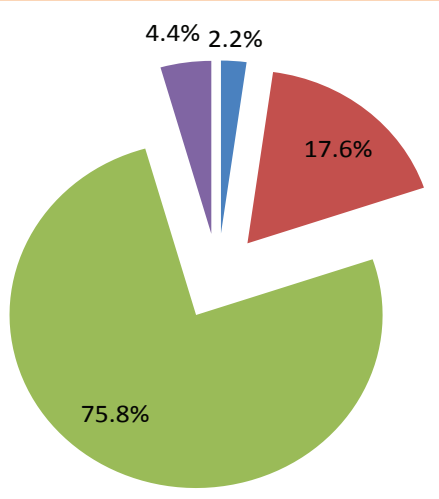

- Less than US \$5000

uS $\$ 5000-10000$

US $\$ 10000-100000$

uS $\$ 100000-500000$

Figure 3. Range of estimated assets

tourism and $48 \%$ is other sectors not mentioned in the questionnaire. It is also clear that no business resides in the energy sector.

Figure 2 shows that $98 \%$ of the SMEs in Libya are private, $2 \%$ are other and there are no governmental enterprises.

It is clear from Figure 3 that the majority of SMEs in Libya, according to this survey, have assets estimated between US\$10000 and $\$ 100000$ (76\%). Enterprises with between US \$ 5000 and 10000 made up 18\% 


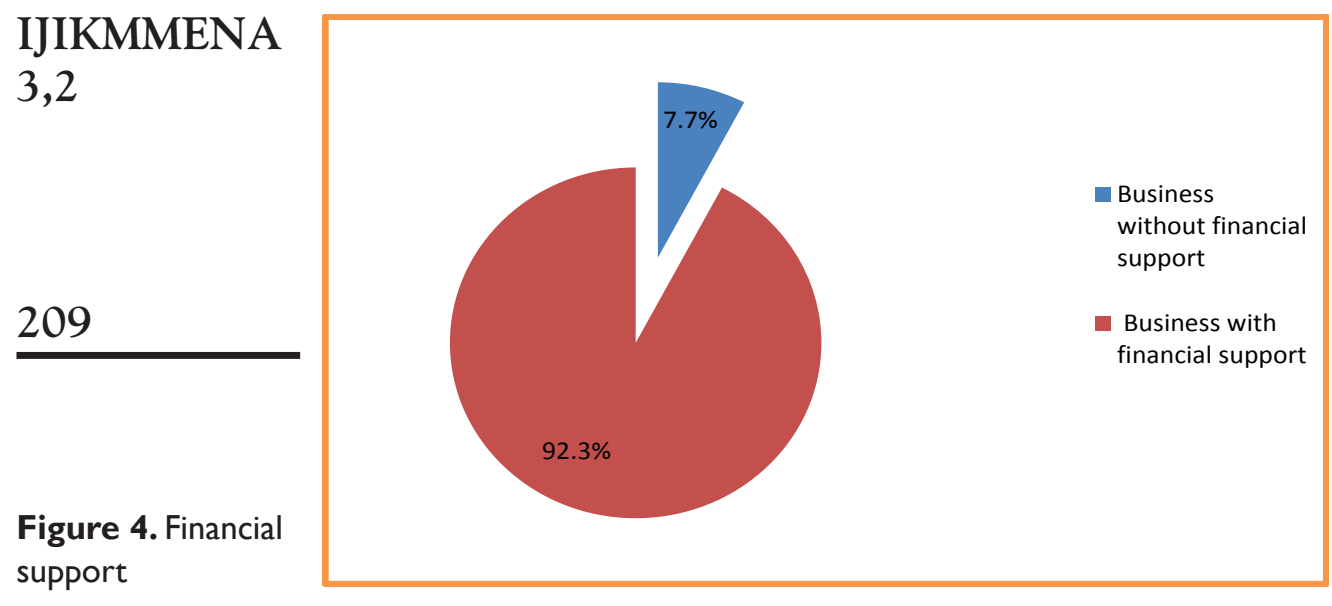

Figure 4. Financial support

\begin{tabular}{lll}
\hline & Frequency & Percentage \\
\hline Very difficult & 37 & $41 \%$ \\
Difficult & 29 & $32 \%$ \\
Uncertain & 25 & $27 \%$ \\
Easy & - & - \\
Very easy & - & - \\
Total & 91 & $100 \%$ \\
\hline
\end{tabular}

of participants, followed by US\$100000 - \$500000 at 4.4\% while those with less than US $\$ 5000$ made up 2\%.

As shown in Figure 4, 92.3\% of the SMEs in Libya have no financial support either from the government or other sources. Although the number of SMEs with financial support is limited, their support comes from either banks or friends and other companies.

\section{THE SOURCE OF BUSINESS FINANCE}

Most responses show that personal savings are the main source of equity finance for SMEs in Libya, at 33\%. The second most common source is help from parents and partners, at $30 \%$ and $21 \%$ respectively. Loans represent only $8 \%$ of the respondents. 
At can be seen from Table 3, 66\% of the responders think that the financial conditions set by conventional banks when they apply for finance to their business are either very difficult or difficult, citing several factors, including: inflexibility, bureaucracy, interest-based loans and centralisation.

\section{THE MAJOR BARRIERS TO SMES INNOVATION IN LIBYA}

Based on the survey sample, shortage of own financial resources for innovation was ranked in first place as a priority regarding barriers to SMEs innovation in Libya (Table 4). The second barrier is the lack of innovation culture in the Libyan educational institutions, followed by shortage of skills in innovation management.

\section{CONCLUSION AND RECOMMENDATIONS}

The importance of SMEs and their role in alleviating poverty, diversifying economic activity, and creating opportunities, must not be ignored. Several countries have proven the success of using SMEs growth and development as a means for national economic development. In many countries around the world, SMEs are becoming a topic of major strategic importance due to their role in revitalising the economy and reducing unemployment. This heightened concern is significant, particularly for the countries that are oil-dependent and seeking to diversify their economic base, such as Libya. However, it is widely recognised that the SMEs sector faces more difficulties than large businesses in terms of accessing finance to be innovative (ElKabbani and Kalhoefer, 2011).

\begin{tabular}{|c|c|c|c|}
\hline Barriers & Yes & No & \\
\hline Insufficient use of public procurement to foster innovation in SMEs & 59 & 32 & \\
\hline Shortage of skills in innovation management & 63 & 28 & \\
\hline Shortage of own financial resources for innovation & 71 & 20 & \\
\hline Shortage of skills to manage intellectual property and knowledge & 55 & 36 & \\
\hline Insufficient knowledge about innovation support services & 49 & 42 & $\begin{array}{l}\text { Table 4. Barriers } \\
\text { to SMEs innovation }\end{array}$ \\
\hline Lack of innovation culture in the Libyan educational institutions & 66 & 25 & in Libya \\
\hline
\end{tabular}

Obstacles to innovation faced by small and medium enterprises (SMES) in Libya 210 
IJIKMMENA 3,2
The first objective of this study was to find out whether the financing problem found by previous researchers still exists. The questionnaire shows that one of the main reasons for the majority of owners of SMEs to avoid bank loans was the terms of the interestbased loans. Bureaucracy was also considered one of the major obstacles preventing project owners from obtaining loans, together with inflexibility and centralisation.

SMEs often have difficulty in obtaining the necessary financial resources to effectively expand/grow their businesses. Libya, like other developing countries, has weak access to traditional growth capital. Most SMEs in Libya use their own savings or that of their partners, thus limiting the development of finance for SMEs. Even where it is available in principle, most SMEs have very low awareness or understanding of it. Where there is awareness, many Libyan SMEs have a cautious attitude towards the issue of interest, regardless of the terms. However, the emergence of Islamic finance should make a significant difference in eliminating this obstacle. Underlying all this is an even more fundamental issue that concerns the relevant knowledge and availability of Islamic funding.

Eltaweel (2011) argued that not only is Libya an extreme case in the use of trade credit on very extended terms but when coupled with inconsistent and unfavourable government policy, this is also a very strong destabilising factor in the Libyan SMEs sector.

The research indicates that most owners of SMEs in Libya are males, which means that females may face more difficulties and constraints due to culture, religion and family ties. Therefore Libyan culture itself may act as a deterrent to the development of innovation in SMEs. This has also been found by the author in his pilot study. The findings of this research have illustrated that based on the results of the questionnaire on innovation, the top six barriers that most hinder SMEs' innovative capacity have been identified as follows:

> Shortage of own financial resources for innovation

$>$ Lack of innovation culture in the Libyan educational institutions

$>$ Shortage of skills in innovation management

$>$ Insufficient use of public procurement to foster innovation in SMEs

$>$ Shortage of skills to manage intellectual property and knowledge

$>$ Insufficient knowledge about innovation support services 


\section{RECOMMENDATIONS}

The findings of this paper indicate that stakeholders in the SMEs process, including SME owners, financiers, banks and the government should undertake new policies and strategies to overcome the challenges confronting SMEs and financing providers. Therefore, the following recommendations should be presented: SMEs in Libya need to have an independent governmental body that can facilitate decision-making related to some important objectives, such as facilitating access to funding from the relevant public and private sectors. Channels of communication with the funding institutions should be opened in order to encourage them to support the sector. Libya has to raise awareness of the importance of innovation and entrepreneurship for economic development. Special programmes and schemes to improve the effectiveness of incubators should be implemented. Development agencies such as Development Banks should be directly involved as key players in establishing institution sponsoring for the interests of small and medium enterprise incubators in Libya.

\section{REFERENCES}

Awang, H. (2004), "Human capital and technology development in Malaysia", International Education Journal, Vol. 5 No. 2, pp. 139-246.

Asiedu, E. and Freeman, J. (2006), "The effect of globalisation on the performance of small and medium enterprise in the US", AEA Conference, Chicago.

Balzat, M. and Hanusch, H. (2004), "Recent trends in the research on national innovation systems", Journal of Evolutionary Economics, Vol. 14, pp. 197-210.

Berry, A. and Levy, B. (1994), "Indonesia small and medium sized exports and their support systems", World Bank Policy Research Working Paper, No.1402, Washington DC.

Bhaird, C. and Lucey, B. (2009), "Determinants of capital structure in Irish SMEs", Available online at < http://link.springer.com> [accessed 3 March 2013].

Birchall, D.W., Chanaron, J.J. and Soderquist, K. (1996), "Managing innovation in SMEs: a comparison of companies in the UK, France and Portugal", International Journal of Technology Management, Vol. 12, pp. 291-305.
Obstacles to innovation faced by small and medium enterprises (SMES) in Libya

212


IJIKMMENA Bolton, J. E. (1971), Report of the Committee of Inquiry on Small Firms, 3,2 HMSO, London.

Burns, P. and Dewhurst, J. (1986), Small Businesses in Europe, Macmillan Press, London.

Dyson, K. (1990), Small and Medium Sized Enterprises, Spicers European Policy Reports, Routledge, London.

Curran, J. and Blackburn, R. A. (2001), Researching the Small Enterprise, SAGE, London.

El-Kabbani, R. and Klhoefer, C. (2011), "Financing Resources for Egyptian Small and Medium Enterprises", Working Paper Series, Faculty of Management Technology, German University in Cairo.

Eltaweel, M. (2011), "Financing of small businesses in the Libyan economic environment", Unpublished $\mathrm{PhD}$ thesis, University of Gloucestershire, UK.

Holmes, S. and Gibson, B. (2001), "The definition of small firms", Final Report, University of Newcastle, Australia.

Gallagher, C. and Stewart, H. (1984), "Jobs and business life cycle in the UK”, Applied Economics, Vol. 18 No. 8, pp. 875-900.

Ghauri, P. and Gronhaug, K. (2005), Research Methods in Business Studies, a Practical Guide, $3^{\text {rd }}$ ed., Pearson Education Limited, England.

Intarakamnerd, P., Chairatana, P. and Tangchitiboon, T. (2002), "National innovation system in less successful developing countries: The case of Thailand", Research Policy, Vol. 31, pp. 1445-1457.

Marcketti, B.S. and Kozar, M.J. (2007), "Leading with relationships: a small firm example, the learning organization", Emerald Group Publishing Limited, Vol. 14 No. 2, pp. 142-154.

Meyer, L.H. (1998), "The present and future roles of banks in small business", Journal of Banking and Finance, Vol. 22 No. 1, pp. 1109. 1116.

McMahon, R., Holmes, S., Hutchinson, P. and Forsaith, D. (1993), Small Enterprise Financial Management: Theory And Practice, Harcourt Brace, Sydney.

Porter, M. and Yergin, D. (2006), "National economic strategy, an assessment of the competitiveness of Libya", The Monitor Group Report, Cambridge Energy Research Associates (CERA), UK. 
Stokes, D. and Wilson, N. (2010), Small Business Management and Entrepreneurship, (6 $6^{\text {th }}$ ed), South-Westem/Cengage Learning EMEA: Thomas Rennie.

UN (2011), United Nations Development Programme, Jordan Human Development Report, (Amman-Jordan) 2011, and the Ministry of Planning and International Cooperation, the Hashemite Kingdom of Jordan.

University of Cambridge. (1992), The State of British Enterprise: Growth, Innovation and Competitive Advantage in Small and Medium Sized Firms, SBRC, Cambridge.

Welch, S. (1975), "Sampling by Referral in a Dispersed Population", Public Opinion Quarterly, Vol. 39 No. 2, pp. 237-245.

Wong, K.Y. and Aspinwall, E. (2004), "Characterising knowledge management in the small business, environment", Journal of Knowledge Management, Vol. 8 No. 3, pp. 44-61.

\section{ABOUT THE AUTHORS}

Emhamad Hamad is a $\mathrm{PhD}$ researcher at Nottingham Trent University. He was a public sector employee from 1985-2005 and has been a Faculty member of the Collage of Economics, Omar Al-Mukhtar UniversityLibya, since 2005. He was a Coordinator of the Faculty of Economics, Al-Qubbah Branch, 2006, Head of the department of Business Administration, Omar Al-Mukhtar University, 2007. Emhamad has given paper at many academic conferences and did his $\mathrm{PhD}$ research on business incubators in the Arab World.

Leslie Arthur is Principal lecturer and Teaching and Learning Coordinator for the School of Architecture, Design and the Built Environment. His interests are in teaching practice and research; this is reflected in over 90 outputs; all roles have been with national validating bodies working as an examiner, editor, writer and verifier. In 2009, Leslie Arthur was short-listed by the Times Higher Education Supplement as one of the most innovative lecturers in the United Kingdom. He has taught in the Nottingham Business School, within the Social Sciences, Design Management and the many disciplines within Art \& Design, from Fine Art to Fashion. He has lectured in Spain, Germany, Denmark, Norway, China, Italy, the USA and Malaysia. He is currently the principal lecturer in Teaching and Learning at Nottingham Trent University.
Obstacles to innovation faced by small and medium enterprises (SMES) in Libya

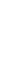

